\title{
Evolution of Academic Freedom in the US Higher Education System as Part of Constitutional Principles
}

\author{
Mindia Ugrekhelidze ${ }^{1}$, Ekaterine Bakaradze ${ }^{2}$ \\ ${ }^{1}$ Prof. Dr., Caucasus International University, Tbilisi, Georgia, mindia.ugrekhelidze@ciu.edu.ge \\ ${ }^{2}$ Assoc. Prof. Dr., International Black Sea University, Tbilisi, Georgia, ebakaradze@ibsu.edu.ge
}

\begin{abstract}
The present paper aims at analyzing the development of academic freedom in the USA as a part of Constitutional principles. The main objective of this research is to identify legal approaches regarding academic freedom, reveal the positive and negative sides of its development. It is essential to study the professional and legal definition of the term to determine its international context, what the notion of academic freedom means for modern society. The research indicates that modern legal constitutional analysis of academic freedom is incomplete for the protection of the interests of academic society. Constitutionally guaranteed academic freedom is limited by state action doctrine, restriction of the principles of freedom of expression of the public figure and judicial decisions, which gives freedom only to the universities and leaves professors' interests without protection when their interests are contrary to the university's interests. Academic freedom guaranteed by the constitution may be incompatible with the concept that implies freely exchanging ideas in the marketplace of ideas, which are likely to be limited by universities. To completely understand and evaluate the importance and purpose of academic freedom, it is necessary to study those cases which led to the establishment of the American Association of University Professors - AAUP and the protection of academic freedom in American universities.
\end{abstract}

KEYWORDS: Academic Freedom, Freedom of Speech, US Constitution, Higher Education, HEI, First Amendment, Supreme Court

\section{Introduction}

Academic Freedom is one of the most significant values of higher education in modern society. After the foundation of the American Association of University Professors (AAUP) in 1915, this statement has been the topic of harsh debates. Menand (1996) called academic freedom as "the key legitimating concept of the enterprise" of the university (Menand 1996, 187-198). Unlike the first half of the 20th century, the concept of academic freedom is universally admitted within the US higher education system though there is a huge difference between its core idea and practical application. Hence, today the disagreement about the importance and usage of academic freedom is more intense than ever.

The research aims to study the problem of academic freedom in the following aspects of US higher education: 1) to determine what was the precondition of the creation of academic freedom concept; 2) to analyze the US Supreme Court's practice and approaches towards the issue based on case studies; 3) to examine how the idea of academic freedom was protected in the past, how it is protected nowadays and in general, how the systemic changes affect the education system; 4) to study the stages of development of academic freedom from the beginning of the previous century and determine how much the enjoyment of academic freedom is protected.

Based on the study aims, the following research methods will be used:

1. Historic - to follow the stages of development of the institute and see the changes that are reflected in a positive or negative result at different stages; theories and definitions regarding academic freedom can be compared to how it worked in HEIs. Although academic freedom is restricted to only those cases which have reached the court, it is still a good basis to carry out further analysis beyond existing theories. It's essential to understand what freedom was meant for academic society, what it achieved and what factors exist in academic life. It should be conducted in the way to preserve American culture, based, created and maintained on the ideals of freedom". To understand the essence of academic freedom, today, we must understand how its importance has grown in the previous century. The research aims at a better understanding of academic freedom by presenting existing theories regarding the issue and also the main current events in the history of higher education. The meaning and purpose of academic freedom will be analyzed, too; 
2. Systemic - to identify the place of the issue within the legal system, an analysis will be conducted based on statements, policy documents and investigations of American Association of University Professors (AAUP) (AAUP's 1915 Declaration of Principles) since 1915 that identified how the notion of academic freedom developed. Acceptance of definitions made by the AAUP as HEIs official policies and incorporation of definitions in contracts concluded with professors has shown how it has become part of the culture of academic society;

3. Theoretical - the theory of academic freedom is mostly evaluated in various articles, monographs, academic editions on intellectual freedom, and legal opinions. The analysis also shows how the value was protected by its advocates, opponents, and how higher education has changed in the US.

The study source is the basic legal acts in the US, legal precedents, as well as papers of individual researchers, analytical materials and assessments, researches concerning academic freedom. The works of scientists involved in the field of education law, political science and pedagogy such as W. Finkin, L. Menand, B. Berg, T. Lawrence, W. Metzger, R. O’Neil, K. Sullivan, and others were analyzed.

\section{Legal Foundation of Academic Freedom - Historical Review}

The US Supreme Court found about 50 years ago that the American "Nation is deeply committed to safeguarding academic freedom, which is of transcendent value to all of us, and not merely to the teachers concerned" (Keyishian v. Board of Regents, 1967). Academic freedom is the subject of the special protection of the first amendment and it is proved by the various court decisions, such as 'Regents of the University of California v. Bakke' (Regents of the University of California v. Bakke 1977). Despite the fact, it is still under a question whether there is any link between the first amendment and academic freedom. The reason for the assumption is that the decisions made by the Supreme Court are very rare, where academic freedom is specifically defined and stated as the 'special subject of care and protection' of the first amendment. It is important to find out, based on the court decisions, whether this opinion is correct and also determine the specific value from the text of the first amendment, which may serve as the basis for the academic freedom doctrine. As it is known, academic freedom as a specific constitutional norm is based on the first amendment. More particularly, only the first amendment protects this value (Metzger 1988, 66). We cannot see any other provisions in the other articles or amendments of the US Constitution that may be applied to it.

In American universities, the term "academic freedom" is often referred to as "a warm and vaguely fuzzy privilege" or as a "moral ideal without conceptual certainty or accuracy" (Finkin, Post 2009 , 6). And yet, what does this term mean and what does it imply? Academic freedom, as a professional definition of the norm, can be found in various documents, but first, let's discuss how it all started.

Before the beginning of the civil war, US HEIs were small, local colleges where the curriculum was classical, the educational mission was less likely to develop and the lecturers were mostly young men who were waiting for their promotion (Finkin, Post 2009, 4, 23). Private donations to institutions were quite small. For example, 50.000 dollars donated for the foundation of Harvard University, was considered as the highest amount. Amherst College was founded on the same amount of money collected from different sources (Hofstadter \& Metzger 1955, 413). After the Civil War, the amount of money was changed and also the type of philanthropy that followed some undesirable consequences for the university autonomy and the intellectual freedom of professors.

Johns Hopkins University was founded in 1867 by a Baltimorean entrepreneur with a donation of 3.500,000 dollars, Leland Stanford Junior University - in 1891 with 24 million dollars left by the railway magnate; University of Chicago - in 1891 with amount of 34 million dollars donated by the oil tycoon John Rockefeller (Hofstadter \& Metzger 1955, 413). Hence, it is not difficult to conclude that the donation amount was directly related to his/her involvement in the management of HEIs. In some way, they acted as entrepreneurs in the field of education. After the civil war, the donors started to look for universities they desired to govern and contributed an appropriate amount of money to be actively involved in decision-making processes on this social basis (Hofstadter \& Metzger 1989, 32-33). Gradually, the position of trustees in the system of US colleges and universities has become more 
business-oriented and this contributed to encouraging conflicts between professors and business interests.

If we look through cases of professors' dismissal in US colleges, one of the most prominent examples can be seen in the Henry Carter Adams case in 1887. He was a lecturer of Cornell University Economics, dismissed for making the Labor Party supporting speech by irritating several members of the Board of Trustees. Further notable cases are also noteworthy, such as dismissal of Edward W. Bemis, lecturer of Economics at the University of Chicago due to express his opinions on antimonopoly issues in 1895; In 1897, the termination of employment contracts for James Allen Smith, Professor of Political Science at Marietta College, due to teaching antimonopoly issues. Furthermore, in 1897, Benjamin Andrews, the President of Brown University, had to resign because the University's regents did not like his support for free silver cutting (Hofstadter \& Metzger 1989, 421). The most notorious case was the dismissal of economics professor Edward Ross in 1900 due to the expression of opinions contrary to views of Stanford University founders and trustees.

Ross, the Protégé (Hofstadter \& Metzger 1989, 16) of professor of economics at the University of Wisconsin - Richard Ellie, defended the leader of the Socialist Party from the Conservatives' critique and supported the free cutting of silver. At the same time, he criticized the situation in the railway when his source of income was the railway tycoon. Ross supported the prohibition of immigration of Chinese, who were cheap railway workers. This was too much for Jane Lathrop Stanford, who, together with the deceased husband, founded the university and by that time was already considered to be the sole trustee. For several years she has been asking the Stanford President David Star Jordan to dismiss Ross and finally, she sent him a letter with the following ending: "Professor Ross cannot be trusted and he should go" (Hofstadter \& Metzger $1955,442-43)$. And he left his job together with other seven professors of the Stanford who also left jobs to protest Ross's dismissal. One of them was philosopher Arthur O. Lovejoy ((Hofstadter \& Metzger 1955, 442), who later founded the American Association of University Professors together with the Columbia University Philosopher - John Dewey (Finkin \& Post 2009, 442-43).

At that time the university professor's employment status was no different from the business worker, whose dismissal was under the discretion of the company's head or board of directors (Finkin \& Post 2009, 3-32). A clear example of aforementioned is the act of George Wharton Pepper, chairman of the Board of Trustees of the University of Pennsylvania, when he dismissed young professor of Wharton Business School Scott Nearing in 1915 for his progressive economic views (Finkin \& Post 2009, 32, cited: Clark 1917). The New York Times newspaper approved this dismissal and confirmed that the trustees were not required to explain the reasons for dismissal (Finkin \& Post 2009, 31, quoting Editorial, Academic Freedom, N.Y. Times, June 20, 191). It was also commonly accepted that the trustee would be able to dismiss the professor even if the latter opposed the founder of the university or one the programs (Finkin \& Post 2009, 32).

As far as we can see, by 1915 the donors and the university administration became so powerful that the professor, offending the administration, politicians or other authorities, was subject to dismissal without any preliminary notice or judicial review. Such individuals, despite the duration and quality of their work at HEIs, could not retain the status of professor and respectively, academic freedom. From this period huge changes were initiated that made significant transformations in the US education system.

\section{Association of University Professors and the 1915 Declaration}

In 1915, when the 'Times' magazine published an article on dismissal case of Professor Nearing, Columbia University economics Professor Edwin Seligman was working on the principles of academic freedom and academic tenure required for the establishment of the AAUP (AAUP, Policy Documents \& Reports 1995, 108).

The AAUP was formed to protect the academic freedom of professors who were persecuted for ideological conflicts (mostly on economic theories). Since 1915, the AAUP studied the alleged violations of academic freedom of professors in university campuses throughout the country, gradually developing and defining the concept and significance of the term. Because of its investigative role and 
political decisions made by AAUP, it was considered to be the only "most influential and important defender of professional tenure and academic freedom." (Lucas 2006, 206)

Without relying on legal precedents, due to the absence of principles linked with academic freedom, the AAUP has established its specific conception, what could be considered and generally, meant under academic freedom. This concept was based on the experience in the real world, from the investigated cases. Before the publication of the Declaration of Principles in December 1915, the AAUP investigated five early cases concerning this issue, which indicated how the authors of the declaration perceived academic freedom. All these cases were focused on the dismissal of professors without prior notice or observance of other procedures. The authors of the Declaration in response, a distinguished number of quasi-legal procedural protections for university academic personnel.

The Declaration text explains three elements of academic freedom (Revealing the influence that the German concept of academic freedom on the American norm, the Declaration refers to Lehrfreiheit (teaching freedom) and Lernfreiheit (learning freedom). This is also evident in the concept of academic freedom mentioned in the Declaration of 1915 in the United States): "freedom of inquiry and research; freedom of teaching within the university or college; and freedom of extramural utterance and action" (O'Neil 2008, 18-20). The Declaration also notes that there are some universities "in which the relation of trustees to professors is still conceived to be analogous to that of a private employer to his employees." It also explains that the trustees can impose their personal opinions upon the teaching of the institutions or dismiss the faculty "to gratify their private negative attitude or resentments." Such behavior undermines the essential principles of modern universities, that should set as their main goals the promotion of inquiry and advance the sum of human knowledge, to develop experts for various branches of the public service.

Declaration confirms that the university should provide an uninfringeable asylum from the dictatorship of public opinion: "it should be an intellectual experiment station, where new ideas may germinate and where their fruit... maybe allowed to ripen until finally... it may become part of accepted intellectual food of the nation or the world. Not less is it a distinctive duty of the university to be the conservator of all genuine elements of value in the past thought and life of mankind which are not in the fashion of the moment."

The Declaration states that according to the principles of academic freedom, the rights granted to the university professors are accompanied by certain obligations. Concerning the research this means "the liberty of the scholar within the university to set forth his conclusions, be they what they may, is conditioned by their being conclusions gained by a scholar's method and held in a scholar's spirit," patiently and sincerely. In terms of teaching, this means that the lecturer, "in giving instructions ..., while he is under no obligation to hide his own opinion ... if he is fit for his position, be a person of a fair and judicial mind; ... should cause ... students to become familiar with the best-published expressions of the great historic types of doctrine upon the questions at issue; and he should, above all, remember that his business is not to provide his students with ready-made conclusions, but to train them to think for themselves..."

According to the Declaration, "for reasons which have already been made evident, inadmissible that the power of determining when departures from the requirements of the scientific spirit and method have occurred, should be vested in bodies not composed of members of the academic profession" (O'Neil 2008, 3). Other bodies or structural units of the university do not have full competence in respect to these requirements and their action may be regarded as a means of achieving other objectives and not as an aspiration of maintaining academic integrity and professional standards. At the same time, granting this authority to only academic personnel implies the obligation to check professional standards. The Declaration of 1915 states: "the university must ensure to purge its ranks of the incompetent and the unworthy, or to prevent the freedom which it claims in the name of science from being used as a shelter for inefficiency, for superficiality, or uncritical and intemperate partisanship." The Declaration uses the same principles alongside with research and teaching, for the so-called extramural utterance - for statements expressed outside the university, whether it is political or other statements, even though they may concern issues that are beyond the professor's academic specialty. It is also noted that "academic teachers are under a peculiar obligation to avoid hasty or unverified or exaggerated statements, and to 
refrain from intemperate or sensational modes of expression." However, as regards the speech in university, the Declaration states that such restrictions should be allowed to be admissible mainly through the public opinion of the profession or, if disciplinary action is appropriate, through the body of members of the academic profession.

The Declaration ends with an issue of great importance for academic freedom: "in short, it is not the absolute freedom of utterance of the individual scholar, but the absolute freedom of thought, of inquiry, of discussion, and teaching, of the academic profession, that is asserted by this declaration of principles." In the final part of the declaration, there are some practical recommendations. One of them implies the establishment of a suitable and appropriate judicial body at the time of the dismissal of the professor or disciplinary liability to enquire, whether the academic freedom was violated. Other recommendations include the protection of academic freedom regarding tenure, as well as the standards for the review of the issue and sending a relevant notice before the dismissal of the professor. In respect of tenure, the Declaration states that the goal of tenure is not the immunization of a member of the faculty towards the disciplinary proceeding against him during hearing proceedings before the faculty or faculty commission.

Although nowadays the values of academic freedom are an integral part of the academic sphere, the Declaration was firstly criticized by the New York Times and further by many other institutions, it was of a huge importance for its founding principles, the ones that made basis for the building of strong institute of academic freedom in the USA.

In conclusion, the Declaration ultimately distinguishes three basic elements of academic freedom: freedom of inquiry and research; freedom of teaching within the university or college; and freedom of extramural utterance and action (Declaration of Principles, The American Association of University Professors, 1915).

\section{0, 1966 and 1994 Statements of the American Association of University Professors}

The interpretation of academic freedom is often based on the definition given in the "1940 Statement of Principles on Academic Freedom and Tenure" that was created by the jointly by the AAUP and the Association of American Colleges (AAC).

In 1940, the AAUP and American College Association, which is now known as the Association of American Colleges and Universities (AACU), agreed to elaborate a short version of the Declaration. Of course, the main purpose of academic freedom was maintained. The text of the document begins with the explanation of the university mission statement (1940 Statement of Principles on Academic Freedom and Tenure) and is noted that the existence of HEIs aims at common good and not the interests of individual teachers or university and the common good "depends upon the free search for truth and its free exposition." Academic freedom is essential for these purposes and includes the following: 1) "full freedom in research and the publication of the results; 2) professors' freedom in the classroom in discussing their subject and 3) freedom to speak to citizens without institutional censorship" (O'Neil 2008, 11). Provisions of the text state that "limitations of academic freedom because of religious or other aims of the institution should be clearly stated in writing at the time of the appointment" (O'Neil 2008, 14).

The 1940 statement refers to the issue of tenure and determines: "after the expiration of a probationary period, teachers ... should have permanent or continuous tenure, and their service should be terminated only for adequate cause, except ... under extraordinary circumstances because of financial exigencies." Tenure and its protection are to ensure "freedom of teaching and research ... and (2) a sufficient degree of economic security to make the profession attractive to men and women of ability" (O’Neil 2008, 14).

The 1940 statement became the standard of academic freedom in the United States. More than two hundred educational institutions and several higher educational institutions have adopted and incorporated it into their charter or regulatory document." (Finkin 2009, 48) In the 1940s, the AAUP was the main defender body for indemnification of damage to the academic personnel who disclosed their negative attitude towards the non-academic society, different opinions or results of research. 
The AAUP's subsequent statements expanded the importance of academic freedom beyond the scope of research, teaching and extramural utterance also includes "statement made in the university." A first, AAUP's 'Statement on Government of Colleges and Universities' of 1966 declared that "the faculty has primary responsibility for such fundamental areas as curriculum, subject matter and methods of instruction, research, faculty status, and those aspects of student life which relate to the educational process" (Statement on Government of Colleges and Universities). That was followed by the 1994 document 'Statement on the Relationship of Faculty Governance to Academic Freedom', which condemned punishment by the administration the members of the faculty who spoke about the violation of academic freedom (1994 Statement on the Relationship of Faculty Governance to Academic Freedom).

\section{The Modern Constitutional Concepts of Academic Freedom}

It is important to evaluate how the term is defined professionally or legally to present to the wide society its international context, particularly, what academic freedom means in modern society. The current legislative constitutional analysis of academic freedom is insufficient for the protection of the interests of academic circles. In our opinion, academic freedom recognized and guaranteed by the Constitution is restricted by following: 1) The so-called "state action doctrine" (state action doctrine, available at https://definitions.uslegal.com/s/state-action-doctrine/); 2) Restriction of the principles of freedom of expression of the public servant and respectively, restriction of enjoyment by it; and 3) Judicial decisions, which gives freedom only to the universities and leaves professors' interests without protection when their interests are contrary to the university's interests. Thus, we may think that academic freedom, guaranteed by the constitution is incompatible with the view that implies the free exchange of ideas, (Polenberg 1999) and what is supposedly restricted by universities.

In this part of the article, a general conception of academic freedom is given that according to the general view, unites its idea in connection with the first amendment of the US Constitution. At the initial stage, this freedom was recognized at the institutional level by court decisions. Indeed, these decisions played a major role at the end of the McCarthy Era (Schrecker 1999). In this period the government was actively interfering in the university's decision-making process. Later, courts have used the principle of freedom of speech and applied it to the university professors' actions, that included in their auditorium, in the lecturing process expressing views that are not related to the teaching, choice of academic courses used by the educational institution, research, and joint management. While some courts did not apply protection of the right of academic freedom of professors in this part but considered the first amendment in general view. Consequently, there is uncertainty about whether the constitutional academic freedom offers professors the right beyond the first amendment, as envisaged for the general public. Some courts consider that academic freedom regardless of what it may mean exists only within the university and not for individual professors.

\section{Connection Between the Values of Academic Freedom and First Amendment of the US Constitutions, Participation of Professors in Democratic Self-Governance}

The courts and the authors of the Constitution commentaries agree that constitutional protection of free speech serves at least one of the following values: 'developing knowledge and 'truth' in the 'marketplace of ideas', promoting democracy and self-government, encouraging individual autonomy, self-expression and self-realization" (Sullivan \& Feldman 2018). In terms of democracy, it is an important interest for the public to take the necessary information to fulfil its function in a democratic society. The second interest that emphasizes the protection of freedom of speech guaranteed by the first amendment is the right of all persons to be able to freely and in accordance with the equality principle express and share the opinion by which a person manages oneself. This form of expression was called by the court "a public discussion" (Cohen v. California 1971; Post 1990) on which Dworkin (Dworkin 1996, 200-01) commented that it is "constitutional for democracy and legitimizing the essential legal system" (Weinstein 2011, 491, 498).

Therefore, we can summarize the values of the first amendment, which protect academic freedom: 1) discovering knowledge and truth in the "marketplace of ideas"; 2) autonomy of professors, which 
includes self-expression and self-realization; 3) providing necessary information for democratic selfgovernment; 4) ensuring individual participation in democratic self-governance.

The aforementioned values - the autonomy of professors and ensuring individual participation in the democratic self-governance can be understood as values protected by the first amendment that mostly justify academic freedom. It is quite difficult to determine the boundaries within which the violation of the academic freedom protected by the Constitution serves for the protection of the interests of employees, including the autonomy-based interest and freedom of speech, to ensure a safe, efficient and fair working environment. However, someone may have a question: why a public person employed in the academic field has to have a higher level of constitutionally protected interest than a public persom employed in another system such as in Skinner v. Railway Labor Executives' Assn. case of 1989, where a similar complaint was first made (Skinner v. Railway Labor Executives' Assn. 1989) by James Weinstein: "There is no justification for endowing university professors with special privileges to engage in democratic self-governance in the workplace or anywhere else for that matter. Indeed, doing so would violate the basic precept of formal equality underlying the individual right to democratic participation" (Weinstein 2013). Furthermore, a workplace, whether it is state or private, is not intended for public discourse or other forms of democratic self-government.

According to this view, academic freedom as a professional norm has never been a justification of individual autonomy or considered as an individual right to democratic participation. In contrast, the AAUP statement of 1940 says that HEIs "is conducted for common good and not to further the interest of either the individual teacher or the institution as a whole. The common good depends upon the free search for truth and its free exposition" (1940 Statement of Principles on Academic Freedom and Tenure). The statement also says that academic freedom is essentially fundamental for research purposes and the so-called "establishment of the truth and promotion of development." We believe that the purpose of the statement was not individually to extend the interests of the professors concerning the universities and set forth establishment the truth in the foreground, confirming that the first amendment justifies neither individual interest nor democratic governance. Moreover, it suggests that the main task of inquiring this issue is to find knowledge and truth as the predominant value of the first amendment in the "marketplace of ideas".

\section{Conclusion}

The contribution to the development of Academic Freedom made by modern American universities is great. Among other measures, this is confirmed by the number of Nobel prizes that American professors have received. There can be no reasonable doubt that academic freedom is integral to the process of creating knowledge, on which depends the progress of society. However, equal protection by the courts and the constitutional norm remains to be the open question.

The paper aimed to offer the role of the Court to be as little as possible in this case. This is because academic freedom has never been considered as a true individual right, but to be a greater extent to encourage "common welfare". According to the Constitution, all three branches of the government should take care of the common good.

The only reason why academic freedom has such a small weight in the constitutional standpoint, as Robert Post has noted, is the knowledge that universities create is essential for democratic selfgovernance.

Any doctrinal rule or standard developed for the protection of academic freedom by the first amendment should be formed with a narrow structure to advance democratic competence. Until now, the main concern of this doctrine should be the prevention of the government from destroying universities as "independent units of professional knowledge". This suggests that significant barricades of the first amendment will then be raised when the government is trying to interfere with the institutional decision-making that hinders the process of transferring knowledge. However, the first amendment should be relatively less applied when it comes to the internal processes within the university and the role of the court should not be outlined in the matters related to the faculty.

As for the real threats of academic freedom that was caused in the McCarthy Era, the AAUP managed to pressure the courts to recognize academic freedom as a legal norm for a distant purpose that 
the judges and not the professors protect and apply norms for academic life. Nowadays, legal protection of academic freedom should be the mission of not only the AAUP but of the whole education system and strict policy should be developed for apparent violations of academic freedom.

\section{References}

1940 Statement of Principles on Academic Freedom and Tenure. Available at http://www.aaup.org/report/1940statement-principles-academic-freedom-and-tenure.

1994 Statement on the Relationship of Faculty Governance to Academic Freedom. Available at http://www .aaup.org/report/relationship-faculty-governance-academic-free.

American Association of University Professors - AAUP's 1915 Declaration of Principles The American Association of University Professors http://www.aaup-ui.org/Documents/Principles/Gen_Dec_Princ.pdf.

American Association of University Professors, 1940 Statement of Principles on Academic Freedom and Tenure, Policy Documents \& Reports 3 (8th ed. 1995). p. 108. https://www.aaup.org/.

Cohen v. California, 403 U.S. 15, 22 (1971). Robert C. Post, The Constitutional Concept of Public Discourse: Outrageous Opinion, Democratic Deliberation, and Hustler Magazine v. Falwell, 103 Harv. L. Rev. 601 (1990)

Declaration of Principles, The American Association of University Professors, 1915. Available at http://www.aaupui.org/Documents/Principles/Gen_Dec_Princ.pdf.

Dworkin, R. 1996. Freedom's Law: The Moral Reading of the American Constitution. Cambridge: Harvard University Press.

Finkin, M., and Post, R. 2009. For the common good: principles of American Academic Freedom. New Haven: Yale University Press, cited: Evans Clark, 1917, Business Men in Control of American Colleges, N.Y. Times Mag., June 10.

Finkin, M., and Post, R..2009. For the common good: principles of American Academic Freedom. New Haven: Yale University Press, quoting Editorial, Academic Freedom, N.Y. Times, June 20.

Hofstadter, R., and Metzger P. 1989. The Development of Academic Freedom in the United States.

Hofstadter, R., and Metzger, W. 1955. The development of A.F. in the United States. New York: Columbia University Press.

Keyishian v. Board of Regents, 385 U.S. 589 (1967). Available at https://supreme.justia.com/cases/federal/us/385/589/.

Lucas, C. J. 2006. American Higher Education, 2d ed.

Menand, L. (Eds.) 1996. The future of academic freedom (pp. 187-198). Chicago: University of Chicago Press.

Metzger, W. P., 1988. Profession and Constitution: Two Definitions of Academic Freedom in America, 66 Tex. L. Rev.

Polenberg, R. 1999. Fighting Faiths: The Abrams Case, the Supreme Court, and Free Speech. Ithaca: Cornell University Press.

Regents of the University of California v. Bakke (1977) / Regents of Univ. of California v. Bakke, 438 U.S. 265 (1978)/ https://supreme.justia.com/cases/federal/us/438/265/; Regents of the Univ. of Michigan v. Ewing)/ Univ. of Michigan v. Ewing, 474 U.S. 214 (1985)/ https://supreme.justia.com/cases/federal/us/474/214/; Grutter v. Bollinger, 539 U.S. 306 (2003) https://supreme.justia.com/cases/federal/us/539/306/.

Schrecker, E. 1999. "Political Tests for Professors: Academic Freedom during the McCarthy Years", The Regents of the University of California.

Skinner v. Railway Labor Executives’ Assn., 489 U.S. 602 (1989).

State Action Doctrine. USLegal. Available at https://definitions.uslegal.com/s/state-action-doctrine/.

Statement on Government of Colleges and Universities, http://www.aaup.org/report/1966-statement-governmentcolleges-and-universities.

Sullivan, K. M., and Feldman N. 2018. Constitutional Law, Constitutional Law, 19th, Supplement (University Casebook Series) 2018th Edition.

Weinstein, J. 2011. Participatory Democracy as the Central Value of American Free Speech Doctrine, 2011, 97 VA. L. Rev.

Weinstein, J. 2013. Academic Freedom, Democracy, and the First Amendment. Available at http://ncpl.law.nyu.edu/wp-content/uploads/resources/Weinstein-FinalPaperwithSupplement_000.pdf. 